\title{
Inheriting System as an Effort to Maintain the Local Culture
}

\author{
Dyah Tjaturrini \\ \{tjaturrini.dyah@gmail.com\} \\ Universitas Jenderal Soedirman, Purwokerto, Indonesia
}

\begin{abstract}
Calengsai is a traditional art collaborating calung, lengger, and barongsai. Calung lengger is a traditional art from Banyumas, while barongsai is from China. This collaboration was driven by both communities' intense interactions. Calung lengger and barongsai have experienced ups and downs through time. Each has been in its glorious moment in a certain period. Calengsai has also begun to experience ups and downs due to the development of science and technology that the entertainments either from home or foreign country are considered more attractive than the existing traditional arts. The existence of communities greatly influences the existence of their traditional arts. The decreasing traditional arts may be caused by their own communities, especially related to the needs of communities whether or not they still want to maintain their traditional arts. Traditional arts may be continuously survived and developed by their own awareness, one of them, by passing them down to the next generations. There are two types of inheriting systems: vertical and horizontal transmission (Berry, 1999) closely related to the cultural and religious values implied in the local wisdom of each region/community.
\end{abstract}

Keywords: Calengsai, collaboration, inheriting system, vertical transmission, horizontal transmission, local wisdom

\section{Introduction}

According to the experts, culture has various distinctive meanings. In broader sense, culture is the entire system of humans' ideas, actions, and works within the framework of social life belonging to the humans' bodies through learning as similarly stated by Koentjaraningrat (1985: 180). Culture is also considered as a system which has a relationship between one and the others. The symbolic forms cover languages, things, music, beliefs, and social activities containing the meaning of togetherness within the cultural coverage. Kluchohn and Kelly in Niode (2007:49) argued that culture is "patterns to live explicitly, implicitly, rationally, irrationally and non-rationally created in the history found in each time as a potential guidance for the humans' behaviours". Referring to those meanings, all cultural activities are intended to meet the people's needs related to their life necessities. In other words, culture may not be separated from the entire patterns of people's activities as culture also has a vital role within the processes of building the character of the nation.

The aforementioned explanations show that culture and the contained values are the foundation to form the character and identity of the nation. Local cultures have the cultural values showing the identity of their supporting communities should be continuously preserved to face the rapid development of science and technology. Local culture may survive and develop when everyone is aware to preserve the culture. One element of culture is art. 
Traditional arts are media or representation of identity of the supporting community. Traditional arts have experienced ups and downs due to the development of science and technology which positively and negatively influence the development of any field including art. The development of science and technology may provide bigger opportunities for cultures from different nations to meet and interact, influence, utilize, and assimilate each other, as well as work together at any field (Caturwati, 2008:100) including arts. Arts are devided into two: traditional and modern arts. Traditional arts in years past had different functions if compared with the present condition. Traditional arts used to function as a ritual instrument. Art is dedicated or done to respect the ancestors, gods, or the creators (Claire Holt, 2000: 124).

Art is one of the seven cultural elements as stated by Koentjaraningrat. Koentjaraningrat explained that culture is universal since found in all cultures of various nations throughout the world. Arts refer to the esthetic values from the expression of humans' interest in the beauty enjoyed through eyes and ears. Along with the development of science and technology, an art work sometimes experience a change either in its functions, intentions, or purposes through innovations and creativities. Art may not be separated from its communities. As one important part of culture, art is an expression of creativity from the culture itself. The communities are those who support the culture that arts may create, provide opportunities to move, maintain, transmit, and develop a new culture (Colletta \& Kayam, $1987: 317$ ).

Each culture belonging to each community has its own values. Cultural values are those agreed and implanted in a community, organizational scope, community environment referring to a habit, belief, symbols with certain characters which may be distinguished each other as the reference of behavior and response to what will happen or is happening. Theodorson in Pelly (1994) stated that value is an abstract matter used as a general guidance and principles to act and behave. People's or groups' bond to values according to Theodorson is relatively strong and even emotional. That's why value may be seen as the purpose of humans' life. Koentjaraningrat (1987:85) described that cultural values consist of the conceptions of life existed in most people's thoughts related to those considered highly valuable. The existing value system in a society is taken as an orientation and reference to act. Therefore, cultural values belonging to someone may influence him/her and determine alternatives, ways, instruments, and purposes of the provided creations. Kluckhohn in Pelly (1994) define cultural values as the organized general conceptions which influence behaviors related to the nature, humans' positions to nature, the relationship one to the others, and related to those desirable or not desirable which may be related to the relationship of people with the environment and the other human beings. Cultural values will soon appear in symbols, slogans, mottos, visions and missions. Cultural values may also be seen in traditional art performances through symbols, song lyrics, accessories, worn costumes and others. Traditional arts certainly have the values followed by their supporting communities. Those values according to Talcot Parson (1959: 215) as quoted by Supriatna who defined values in local cultures as an element in a conventional symbolic system which has the role as criteria in selecting various alternatives provided in the established situations. Those nations possessing local cultures in the form of value systems may be used as the local culture supporting instruments to face various challenges and continuously develop.

If not well maintained and preserved, those traditional arts will soon extinct. The most real traditional art example is calung lengger in Banyumas. The other arts (from outside Banyumas) are considered more attractive and decrease young generation's acknowledgement and understanding to calung lengger as a traditional art from Banyumas. It is rarely found that children and teenagers who can do lengger dance. It was recognized when Banyumas held a lengger festival at regency level in 2012. Banyumas regency has 20 districts, but only 3 
districts participated in that lengger festival. A lengger must be able to dance and sing (known in Javanese as nembang/nyinden), while not all lengger dancers can sing. To overcome those problems, the festival was changed into lengger dance festival (an interview with Mr. Carlan, 2018). One effort made by the calung lengger art workers is combining calung lengger with barongsai. The collaboration of these three arts is known as calengsai.

From the results of interviews with the informants and factual proofs from the field, the author then intents to deeply discuss and tries to find the best solutions to maintain these marginalized traditional arts. Thus, two questions arise in this paper.

\section{Theoretical Review}

In maintaining traditional arts, one effort to make is through the cultural inheriting system. Inheriting system is divided into two types: Vertical Transmission and Horizontal (Berry, 1999). Vertical Transmission is inheriting system made through a genetic mechanism passing down from time to time across generations involving inheriting the cultural characteristics from parents to children and the next generations. Vertical transmission is also known as Biological Transmission. In this system, parents inherit values, skills, beliefs, and cultural motives to their children and so forth. This is what happens when inheriting the local culture of calung lengger, in which skills are passed down. Horizontal Transmission is inheriting system made through both formal and informal institutions, such as schools or art studios. In maintaining the traditional arts, such as calung lengger, Horizontal Transmission is implemented (Berry, 1999). Horizontal transmission is received from schools or formal institutions, apart from happening in their own cultures or others'.

\section{Methodology}

This study employs a qualitative method since it has an emic perspective which means that the obtained data are in the form of narrations, detail stories, expressions, and original language resulted from the constructions of various informants and respondents without any evaluation and interpretation made by the author. Data in the form of stories may only be obtained through in-depth interviews and observations, not questionnaires (Saifudin, 2005:31). According to Creswell, a qualitative research involves methods to explore and understand meanings conducted by several individuals or individual groups. The qualitative research processes are conducted by giving various questions, collecting specific data from participants, inductively analyzing the data, and interpreting the data meanings. Grounded theory is the selected research design for this study. In this research study, the literatures are presented at the end of the research, as the bases to compare and distinguish the qualitative research findings. Literatures do not guide and direct the research but utilized as the assisting facilities when the patterns or categories are determined (Creswell, 2014).

A qualitative research mainly concerns on processes instead of results. Data and information are required to answer the questions of what, why, and how to reveal the processes. This research is also considered inductive since it is started from the field as the empirical facts. The researcher directly goes to the field, learn the naturally constructed processes or findings, writing, analyze, interpret, report, and draw conclusion from those processes. This research is also considered as a descriptive analytical study. The data obtained 
from interviews, observations, picture taking results, recording results, and questionnaires are presented not in the form of figures. The researcher immediately analyzes the data by enriching information, finding relationship, comparing, finding patterns based on the real data (not transformed into figures). The results of data analysis are in the form of descriptions about the situations under study and then presented in the form of narrative descriptions.

\section{Discussion}

Banyumas is one city in Central Java province possessing various cultures. Local cultures including traditional arts will remain survive and develop when inherited to the next generations. The existing traditional arts are various. Calung lengger is classified into one traditional art from Banyumas continuously decreasing due to the development of science and technology as well as caused by no regeneration nor inheriting system that its existence may not be well maintained. To overcome those problems, the communities who support the traditional arts should make the necessary efforts to preserve those traditional arts from extinction due to the development of science and technology.

The development of science and technology positively influences the development of local arts including calung lengger in Banyumas. Various arts coming from foreign countries through social media have made traditional or local arts start to be abandoned as considered no longer attractive. To remain survived and well maintained, traditional arts should be innovated and collaborated with the other arts to create more attractive art.

Inheriting system used by the art workers is the horizontal transmission taught through formal institutions, such as schools and universities by establishing student activity centers (known as Unit Kegiatan Mahasiswa/UKM) particularly related to the traditional arts. according to the dance instructo at State Senior High School 1 (SMA N 1) Purwokerto, Ms. Endang, has started teaching lengger dance to the students through dancing extracurricular available at the school that she can express herself and teach the students with both traditional and contemporary dances, including lengger. Through this extracurricular, State Senior High School 1 Purwokerto may send those students to represent Banyumas in particular events, such as those held by the Youth, Sports, Culture, and Tourism Office (known as Dinporabudpar/Dinas Pemuda, Olahraga, Budaya dan Pariwisata) of Banyumas. Those events are as follows:

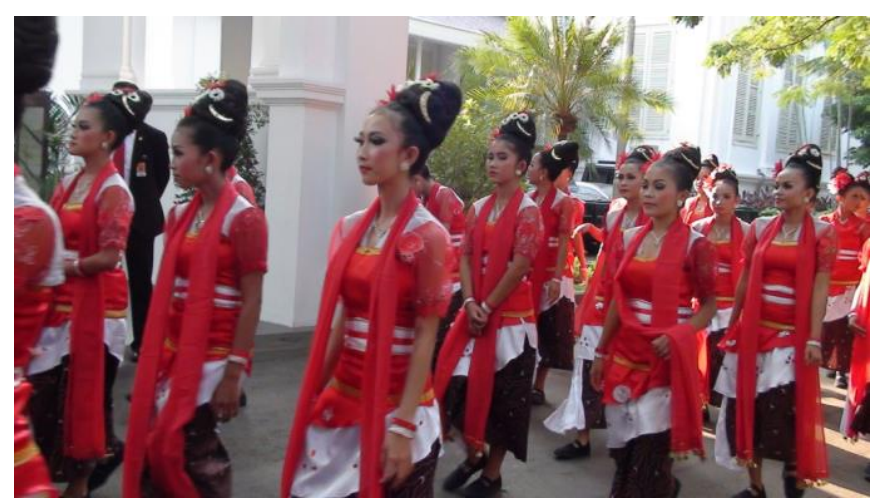

Fig. 1. The Comemoration of Indonesian Independence Day on August 17, 2011 at the State Palace 
President of Indonesia, Susilo Bambang Yudhoyono, once wanted lengger dance to perform at the commemoration of Indonesian Independent Day in 2011. Besides, lengger dance has also been performed at the event of Central Java Visit 2013.

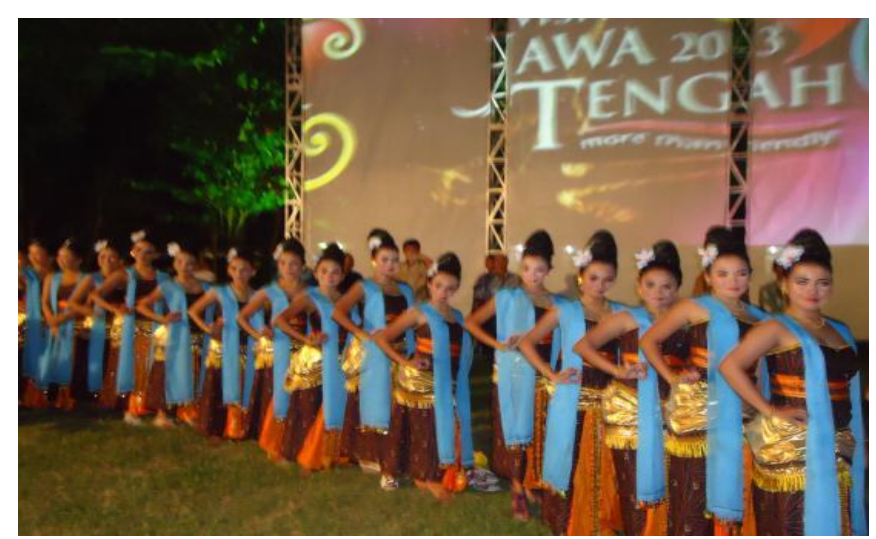

Fig. 2. Central Java Visit 2013 in Yogyakarta

During the event of Central Java Visit 2013 in Yogyakarta, the lengger dancers were coming from the students of State Senior High School 1 Purwokerto. They did not dance the traditional but contemporary lengger modified by Ms. Endang Setyaningsih, the lengger dance instructor at State Senior High School 1 Purwokerto. She highly concerns on traditional arts that she is in cooperation with the Youth, Sports, Culture, and Tourism Office (known as Dinporabudpar/Dinas Pemuda, Olahraga, Budaya dan Pariwisata) Purwokerto, to continuously activate the traditional arts by inheriting those arts through extracurricular activities at State Senior High School 1 Purwokerto.

The highly-encouraged extracurricular activities regularly practiced at schools are the efforts made by the art workers collaborating with the government.

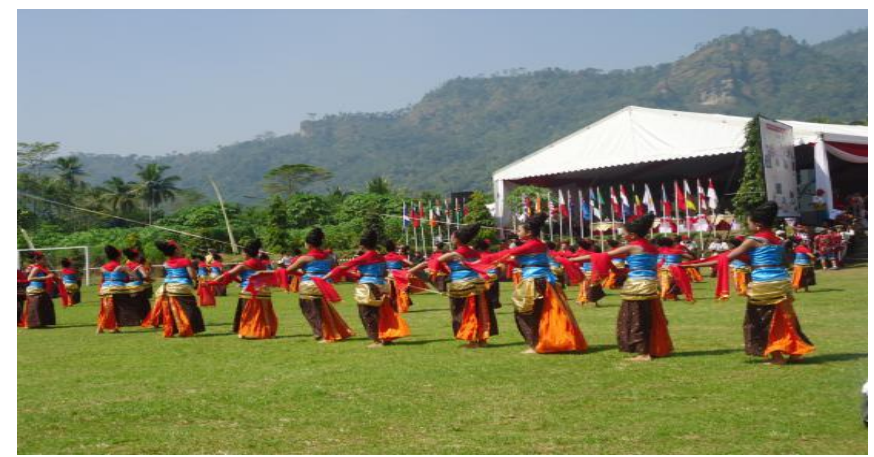

Fig.3. Demokrat Political Party Anniversary Event in 2011 (A Private Collection of Ms. Endang Setyaningsih) 


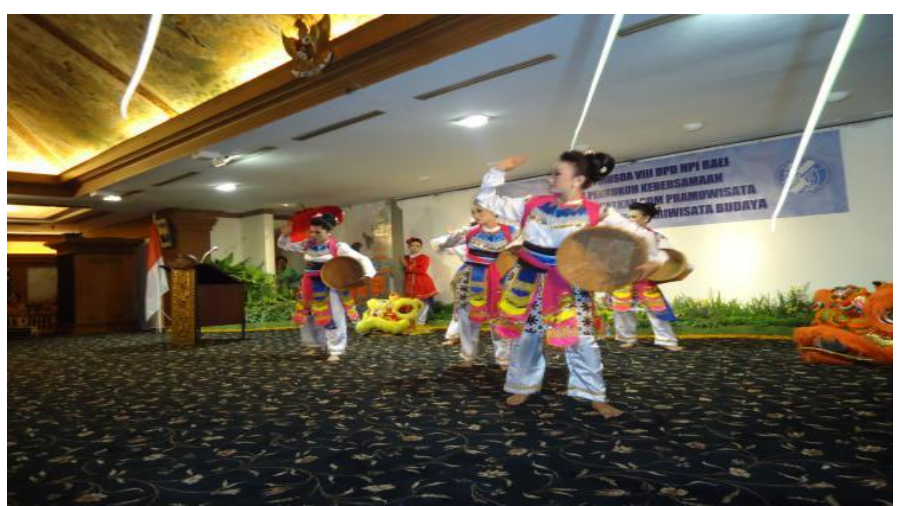

Fig. 4. the Twentieth Regional Meeting of Indonesian Tourism Association (Musda HPI ke XX) in Bali, 2012 (A Private Collection of Ms. Endang Setyaningsih)

The event held at the twentieth meeting of Indonesian Tourism Association (HPI ke XX) in Bali has proven that the inheriting system made at schools is through extracurricular activities. At this event, the inheriting system was made by the art workers, including the inter-cultural and inter-community collaboration. The traditional art of calung lengger is collaborated with barongsai, known as calengsai. When in Bali, the calengsai performance took a traditional theme of Banyumas People using the collaboration of inter-region musical instruments from Bali and Java with the typical Chinese Costumes.

Calengsai was derived from the word calung, lengger, and barongsai. The collaboration between the Banyumas people's and Chinese-descendent people's cultures was initiated by the Banyumas Regent, Mardjoko, within his governing period of 2008 - 2013. He highly concerned and understood the situations and conditions of the existing traditional arts in Banyumas, especially in Purwokerto. Mardjoko also wanted to see the harmonic social life between the indigenous people and Chinese-descendent people in Banyumas (an interview with Mr. Rawuh on 23 November 2017 at 2 p.m.). He suggested to collaborate calung lengger and barongsai into one and then known as Calengsai. This collaborated art is not only as one effort to avoid misunderstanding between the indigenous people and Chinese-descendent people in Banyumas but also to preserve the traditional arts through innovations (Yusmanto, Kompasiana 2015). The underlying basis was the philosophical values followed by the Banyumas People teaching that life should be in harmony among the communities. Thus, this cultural preserver from East Purwokerto district united both communities of the indigenous Banyumas people and Chinese-descendent people living in Banyumas (Noveni, 2011).

Calengsai is a product resulted from the acculturation between banyumas and Chinese cultures. Cultural acculturation may result in new art products without eliminating the uniqueness or characteristics of those traditional arts. An innovator is greatly required to create art in the other preferable art performances. This encouraged Ms. Sri Rahayu, the cultural preserver, to make various efforts to realize her creative ideas initiated by the former regent Mardjoko to unite calung, lengger, and barongsai. This traditional art is then collaborated, innovated, and existed together with one Chinese culture, that is, barongsai (Hoon, 2006:30). Calengsai is a product of acculturation arising from the problems of Banyumas and Chinese cultural representation and identity.

The development of industrial, communication, and information technology in this recent globalization era has widely opened more opportunities to the cultural meeting and interactions among nations throughout the world which influences, utilizes, mixes, assimilate, 
and cooperate each other at any field as the unavoidable social reality. This may greatly impact and influence most life aspects in social life, either related to cultural behaviors, norms, ethics, traditions, or expressions. Like it or not, delighted or not, willing or unwilling, ready or not ready, the world has come to the openness direction (Caturwati, 2008:101). This is of course a dilemma for each community that they should accept those influences at any life aspect including the art and culture aspect. Each art and culture is actually considered as a representation instrument and identity for its supporting communities and the art workers. The development of science and technology has forced them to find ways that the exiting traditional arts should be well maintained and preserved. The art workers should make new innovations and creativities to encourage the viewers to become more interested in the traditional arts that their existence is well maintained. Similarly, it happened to calung lengger and barongsai. Innovations and creativities made by the art workers of these arts are combining calung lengger and barongsai into calengsai. Calengsai is positively responded by both indigenous and Chinese-descendent people in Banyumas.

The considered more interesting Foreign arts make the decreasing number of young generations to acknowledge and understand calung lengger as one Banyumas traditional art. It is rarely found that children and teenagers who can do lengger dance. It was recognized when Banyumas held a lengger festival at regency level in 2012. Banyumas regency has 20 districts, but only 3 districts participated in that lengger festival. A lengger must be able to dance and sing (known in Javanese as nembang/nyinden), while not all lengger dancers can sing. To overcome those problems, the festival was changed into lengger dance festival (an interview with Mr. Carlan, 2018). Inter-art collaboration may result in new arts such calengsai is one effort to maintain and preserve the traditional arts continuously degraded by the modern arts.

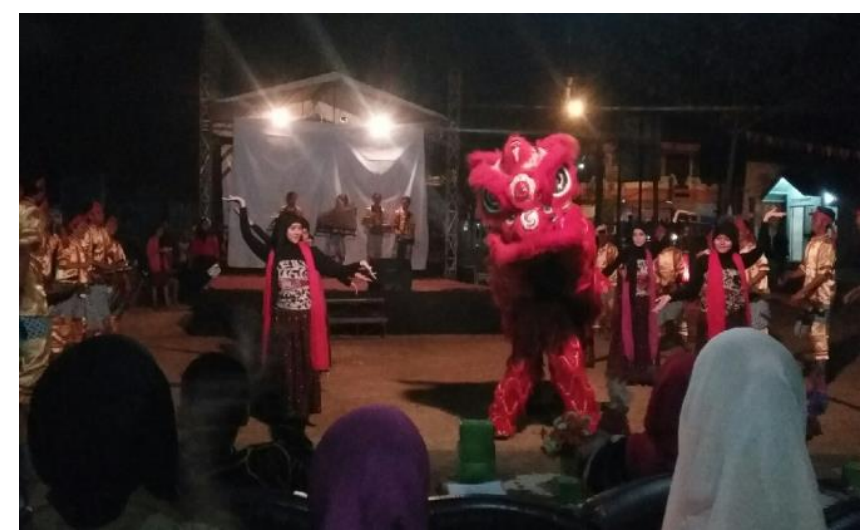

(Source: a Private Collection of Khoirunnisaabidah and Nugraha Trisatya)

Fig.5. Calengsai Performance at Dies Natalis 1 of Faculty of Humanities, Jenderal Soedirman University

Picture 5 above is a collaboration performance of calung lengger, and barongsai held at Dies Natalis 1 of Faculty of Humanities, Jenderal Soedirman University. The performance was made by the students of Faculty of Humanities, Jenderal Soedirman University regularly practicing through the student activity unit at Faculty of Humanities, Jenderal Soedirman University. The horizontal transmission was also made in this student activity unit as implemented at the other formal institutions through their extracurricular activities or student activity units. The events participated by the lengger dance have proven that the traditional 
arts are still well maintained to the present although they have been transformed into new forms called contemporary arts (an interview with Endang Setyaningsih, lengger dance instructor at State Senior High School 1 Purwokerto).

\section{Conclusion}

Art is one of the seven cultural elements as stated by Koentjaraningrat. Koentjaraningrat explained that culture is universal since found in all cultures of various nations throughout the world. Arts refer to the esthetic values from the expression of humans' interest in the beauty enjoyed through eyes and ears. Along with the development of science and technology, an art work sometimes experience a change either in its functions, intentions, or purposes through innovations and creativities. Art may not be separated from its communities. As one important part of culture, art is an expression of creativity from the culture itself. The communities are those who support the culture that arts may create, provide opportunities to move, maintain, transmit, and develop a new culture (Colletta \& Kayam, $1987: 317$ ).

Not only through creativities, are traditional arts also maintained by the art workers in cooperation with the local government using horizontal transmission system. Horizontal transmission is inheriting arts and cultures made by schools or formal institutions in the form of extracurricular and student activity units. Through horizontal transmission, the traditional arts of calung lengger may be continuously maintained although it is slightly shifting. The shifting, in fact, does not eliminate the uniqueness and characteristics but enrich each traditional art. Calengsai performance has a better development. It is shown that horizontal transmission system made by the art workers and government has resulted in proper solutions to maintain and preserve the traditional arts. at present, the traditional arts consisting of calung, lengger, and barongsai have become one traditional art representing the existence of indigenous and Chinese-descendent people in Banyumas.

\section{References}

[1] Berry, JW .1988. Field Methods in Cross Cultural Research. Sage Publications, London

[2] --------. Immigrations, Acculturation, and Adaptation. Queens University. Canada

[3] Bordieu, Piere ,1977. Translated by Richard Nice. Outline of A Theory of Practice. Cambridge University Press. London

[4] ------.-. in D. Hendropuspito, OC. 1989. Sosiologi Sistematik [Sistematic Sociology]. Kanisius, Jakarta, page 149.

[5] Borofsky, R. 1994, The Culture in Motion dalam R. Borofsky (ed), Assesing Cultural Anthropology, Mc.Graw-Hill, New York

[6] Cannadine, D. 1992. The context, performance and meaning of ritual: The British monarchy and the inventon of tradition, c 1820-1977. In E. Hobasbawm and T. Ranger (eds) The Invention of Tradition. Cambridge:Canto

[7] Caturwati, Endang. 2008. Tradisi Sebagai Tumpuan Kreativitas Seni [Tradition as a Group of Art Creativities]. Bandung: Sunan Ambu STSI Press

[8] Colleta, Nat J dan Umar Kayam. 1987. Kebudayaan dan Pembangunan Sebuah Pendekatan Antropologi Terapan di Indonesia [Culture and Construction: An Applied Anthropological Approach in Indonesia]. Jakarta : Yayasan Obor Indonesia

[9] Creel, HG. 1990. Alam Pikiran Cina, Sejak Konfusius Sampai Maozedong [Chinese Thinking Nature, since Confusion to Moozedong]. Yogyakarta: Tiara Wacana Yogya 
[10] Creswell. JW. 2010. Research Design. Pendekatan kualitatif, Kuantitatif, dan Mixed [Qualitative, Quantitative, and Mixed Approach]. Third Edition (Translation). Yogyakarta : Pustaka Pelajar

[11] Doubler, Margareth N.H. 1959. Tari, Sebuah Pengalaman Kreatif [Dance, a Creative Experience] Translated by Dewi Nurani dan A.Tasman. Medison, The University of Winconsin Press

[12] Geertz, Clifford. 1973. The Interpretation of Culture, Basic Books

[13] Hall, Stuart. 1997. Cultural Identity. Sage Publication, London.

[14] .................. 2003. Representation: Cultural Representations and Signifying Practises. Publication, London. 